\title{
Article \\ Different Organic Fertilisation Systems Modify Tomato Quality: An Opportunity for Circular Fertilisation in Intensive Horticulture
}

\author{
Isidoro Carricondo-Martínez ${ }^{1}$, Francesca Berti ${ }^{1}$ and Maria del Carmen Salas-Sanjuán ${ }^{2, * \mathbb{D}}$ \\ 1 Doctoral Program in Protected Agriculture, Campus de Excelencia Internacional Agroalimentario, ceiA3, \\ Almeria University, 04120 Almeria, Spain; icarricondo@ingenieroagricola.org (I.C.-M.); \\ Francesca.berti1560@gmail.com (F.B.) \\ 2 Department of Agronomy, Campus de Excelencia Internacional Agroalimentario, ceiA3, Almeria University, \\ 04120 Almeria, Spain \\ * Correspondence: csalas@ual.es
}

check for

Citation: Carricondo-Martínez, I.;

Berti, F.; Salas-Sanjuán, M.d.C.

Different Organic Fertilisation

Systems Modify Tomato Quality: An Opportunity for Circular Fertilisation in Intensive Horticulture. Agronomy 2022, 12, 174. https://doi.org/ 10.3390/agronomy12010174

Academic Editors: Maria Angeles Bustamante Muñoz and Raul Moral Herrero

Received: 26 November 2021 Accepted: 21 December 2021 Published: 11 January 2022

Publisher's Note: MDPI stays neutral with regard to jurisdictional claims in published maps and institutional affiliations.

Copyright: (C) 2022 by the authors. Licensee MDPI, Basel, Switzerland. This article is an open access article distributed under the terms and conditions of the Creative Commons Attribution (CC BY) license (https:// creativecommons.org/licenses/by/ $4.0 /)$.

\begin{abstract}
The valorisation of vegetal waste as a source of crop nutrients constitutes a circular strategy to improve the sustainability of intensive horticultural production systems. The main goal of this study was to evaluate the effects of organic amendments derived from vegetal residues on the yield and quality of tomato. The following fertilisation treatments were carried out: fresh vegetal residues $\left(4 \mathrm{~kg} \mathrm{~m}^{-1}\right)$, compost $\left(3 \mathrm{~kg} \mathrm{~m}^{-1}\right)$, and vermicompost at two different doses ( 3 and $\left.9 \mathrm{~kg} \mathrm{~m}^{-1}\right)$, all derived from previous tomato crop vegetal residues, an organic treatment with goat manure $\left(3 \mathrm{~kg} \mathrm{~m}^{-1}\right)$, and a control mineral fertigation treatment. The highest yield was obtained with conventional mineral fertigation management, followed by vermicompost treatments at two different doses ( 3 and $9 \mathrm{~kg} \mathrm{~m}^{-1}$ ), with no statistical differences. The organic treatments with fresh crop residues, compost and goat manure resulted in lower yield. Regarding quality parameters, the lycopene content was higher in the mineral fertilisation and vermicompost at $3 \mathrm{~kg} \mathrm{~m}^{-1}$ treatment, while the other antioxidants measured were more concentrated in tomatoes fertilised with vermicompost treatment at $9 \mathrm{~kg} \mathrm{~m}^{-1}$ and goat manure. The plant nutrient management with vermicompost is the best circular solution, as it allows to reintegrate the residues generated in previous crop cycles into the soil, obtaining a yield equal to chemical input management and tomatoes with high nutritional quality.
\end{abstract}

Keywords: vegetal waste; vermicompost; compost; tomato; organic fertilization

\section{Introduction}

The current intensive agriculture model is based on a linear approach of "extractingusing-consuming-disposing" [1], characterised by a high consumption of external resources [2]. In Almeria (SE Spain), the region with the highest concentration of greenhouses in the word, every year, 85,294 tons of organic waste are generated from the horticulture sector [1]. Vegetal waste may be considered as a problem, since its inappropriate management causes huge environmental and human health issues [1,3], but also as a big opportunity. The recycling and reuse of organic waste constitute a circular strategy that is essential to improve the sustainability of intensive production systems [3,4].

In intensive horticultural systems, conventional fertilisation is based on minerals. Mineral fertilisers improve crop productivity as they guarantee the fast replacement of nutrients [5], but their long-term use and over-use deteriorate soil fertility and soil microbial population [6], increase soil erosion and acidification [7] and lead to ground-water pollution [1]. Moreover, the production and transport of chemical fertilisers contribute to $\mathrm{CO}_{2}$ emissions [8]. The addition of animal-derived manure at the beginning of the crop cycle is also common practice (Figure 1). 


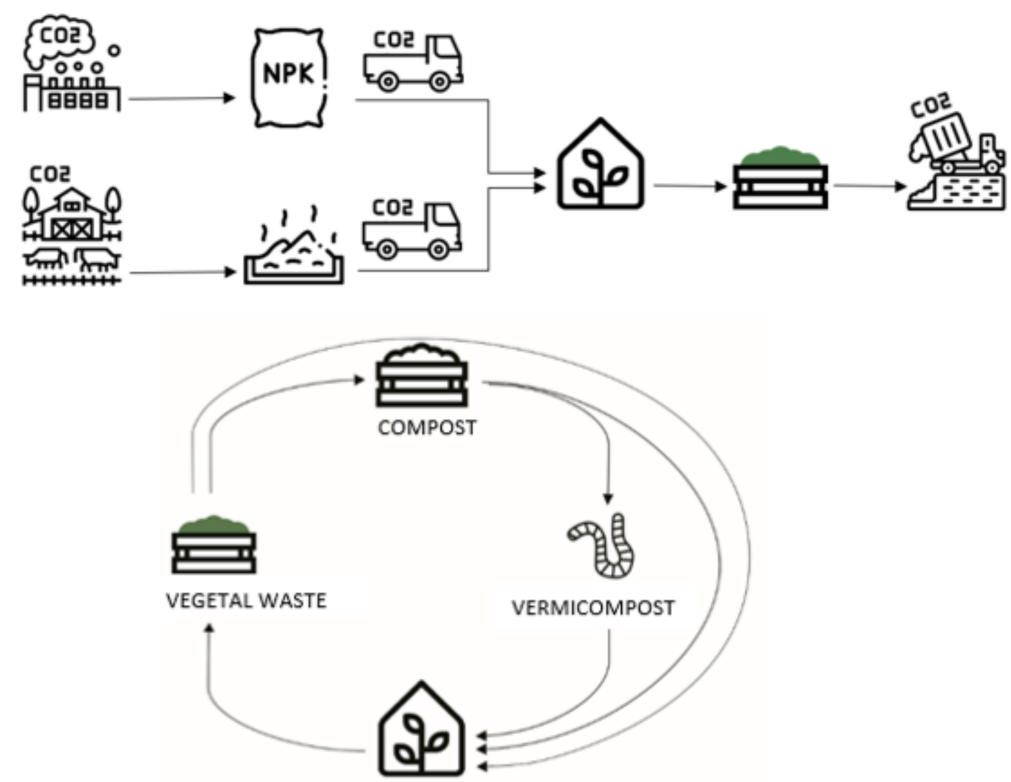

Figure 1. Conventional fertilisation and waste management (top) and circular fertilisation and waste management (bottom).

Using vegetal waste generated within the same production site as a source of crop nutrients must be considered as an advantage for the farmer, as it allows a reduction in the use of external fertilisers [4,9], while decreasing transport and waste management costs. Furthermore, organic fertilisation has a fundamental role in improving soil structure and fertility [10], enhancing chemical, physical and biological soil properties [11] and increasing soil $\mathrm{C}$ sequestration [12]. Vegetal waste can be incorporated into the soil directly as fresh residues but considering the high amount of residues generated for each crop cycle, processes of composting or vermicomposting should be considered in order to improve the organic matter's nutritional characteristics and to stabilise the biomass (Figure 1).

Nowadays, consumers are more aware about environmentally sustainable production practices and food safety, and organic products are perceived as healthier and more nutritious than conventional ones [13-15]. Some authors have reported higher-nutritional quality crops when organic fertilisers were applied $[4,12,16]$, while others have reported no effects on the quality of organic crops [17].

Tomato, due to its health benefits, is one of the most important horticultural crops in the world [18], being an important source of nutrients and antioxidants such as carotenoids, ascorbic acid and polyphenols [19,20]. Bilalis et al. [21], in an open field experiment, obtained the highest lycopene content in tomatoes fertilised with seaweed compost $\left(2000 \mathrm{~kg} \mathrm{ha}^{-1}\right)$ compared with tomatoes managed with inorganic fertiliser. This was attributed to the highest nitrogen availability in inorganic fertilisation management, which increases leaf area and shading, thus reducing solar radiation, essential for lycopene synthesis. Wang et al. [22], evaluating four fertilisation treatments (no fertiliser, urea, chicken manure compost and vermicompost) in soils with different years of continuous cropping $(0,5,20$ years), found that vermicompost improved tomato quality. However, few studies have been performed to evaluate the effects of vegetal residues produced in the same field as a source of crop nutrients.

In this context, it was hypothesized that: (1) vegetal waste generated within the same farm can be used as a fertiliser for tomato crops, replacing standard mineral fertigation; (2) the use of organic fertilisers could equal yield obtained with minerals; and (3) the use of organic fertilisers could improve the tomato nutritional quality. The objective of this study was to evaluate the effects of different vegetal waste-derived amendments, fresh vegetal residues, compost and vermicompost (at two different doses), (i) on tomato yield, (ii) and on tomato chemical and physical proprieties. 


\section{Materials and Methods}

\subsection{Field Experiment Design}

The experiment was carried out in a continuous cropping system inside a $1200 \mathrm{~m}^{2}$ greenhouse located in Nijar (Almería, Spain), between August 2019 and January 2020. The greenhouse was an "Almeria type greenhouse" (Raspa y Amagado) with passive climate control with zenithal windows.

Tomatoes (Solanum lycopersicum L.) cv. 'Surcal' (Natursur S.C.A.), grafted onto Beaufort (Monsanto) rootstock, were transplanted on 22 August 2019, in an area of $650 \mathrm{~m}^{2}$, with a density of 0.66 plants $\mathrm{m}^{-2}$, staked and growing with two stems. Pollination was carried out by bumblebee; pest control was conducted following the integrated production standards. Before the experiment, the greenhouse had previously been cropped with 5 cycles of tomatoes over 3 years. The organic plots were managed with the same amendments as in the presented study. Amendments were applied to the organic plots in February 2017, February 2018 before transplanting, and the last application was made in August 2019 before starting the crop cycle examined in this experiment (Figure 2). The basic chemical properties of the soil are presented in Table 1.

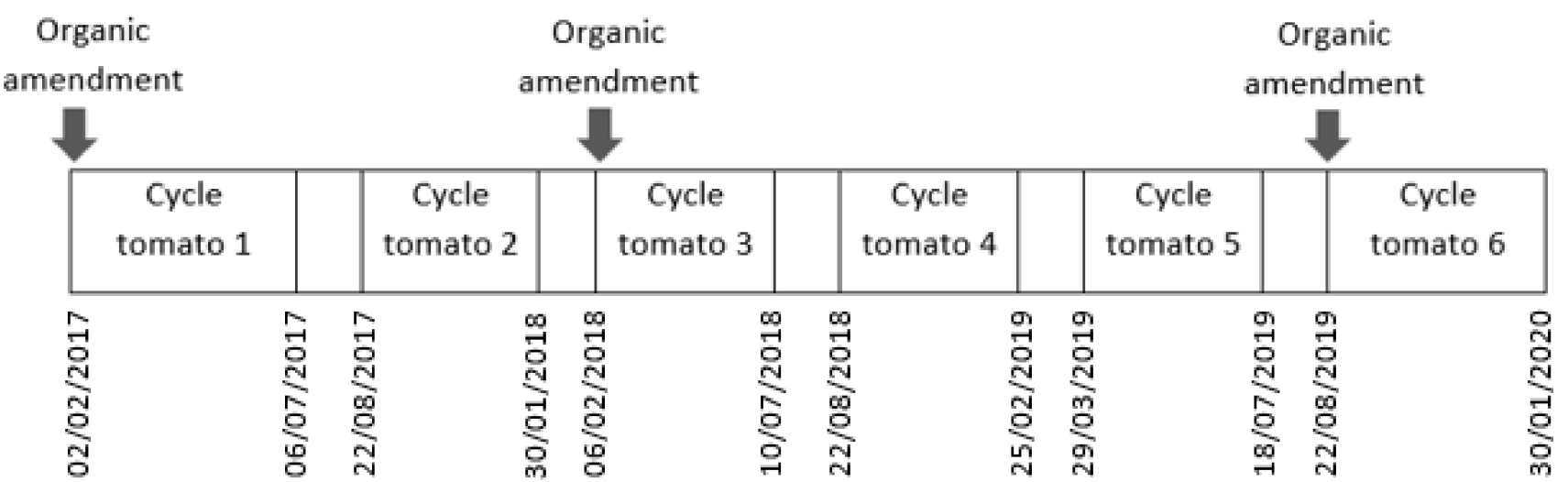

Figure 2. History of the organic plot from cycle 1 to cycle 6. Cycle tomato 6: crop cycle examined in this study.

Table 1. Physiochemical properties of the original soil at the beginning of the experiment.

\begin{tabular}{|c|c|c|c|c|c|c|c|c|c|c|c|c|c|}
\hline $\mathrm{pH}$ & E.C. & O.M. & N Kjeldahl & $\mathrm{C} / \mathrm{N}$ & $\mathrm{N}-\mathrm{NO}_{3}{ }^{-}$ & $\mathrm{PO}_{4}{ }^{2-}$ & $\mathrm{K}^{+}$ & $\mathrm{Ca}^{2+}$ & $\mathrm{Mg}^{2+}$ & $\mathrm{Na}^{+}$ & Sand & Silt & Clay \\
\hline 8.3 & 2360 & 0.93 & 0.07 & 7.7 & 47.0 & 120 & 1000 & 5160 & 973 & 566 & 53.5 & 12.4 & 34.1 \\
\hline
\end{tabular}

$\mathrm{pH}$ (volume soil-water 1:2.5); E.C. (electrical conductivity, $\mu \mathrm{S} \mathrm{cm}^{-1}$ ); O.M. (organic matter, $\%$ dry matter (dm)) $\mathrm{N}$ Kjeldahl (nitrogen Kjeldahl, \% dm); $\mathrm{N}^{-N_{3}}{ }^{-}$(nitrate nitrogen, $\mathrm{mg} \mathrm{L}^{-1}$ ); $\mathrm{PO}_{4}{ }^{2-}$ (phosphate, $\mathrm{mg} \mathrm{L}^{-1}$ ); $\mathrm{K}^{+}$(potassium, $\left.\mathrm{mg} \mathrm{L}^{-1}\right) ; \mathrm{Ca}_{2}{ }^{+}\left(\right.$Calcium, $\left.\mathrm{mg} \mathrm{L}^{-1}\right) ; \mathrm{Mg}^{2+}$ (magnesium, $\left.\mathrm{mg} \mathrm{L}^{-1}\right) ; \mathrm{Na}^{+}$(Sodium, $\left.\mathrm{mg} \mathrm{L}^{-1}\right)$; sand (\%); silt (\%); Clay $(\%)$.

The following fertilisation treatments were tested: vegetal residues from previous tomato crop applied at $4 \mathrm{~kg} \mathrm{~m}^{-1}(\mathrm{CR})$, composted organic waste of previous crop applied at $3 \mathrm{~kg} \mathrm{~m}^{-1}$ (CO), vermicompost of organic waste of previous crop applied at $3 \mathrm{~kg} \mathrm{~m}^{-1}$ (V3) and at $9 \mathrm{~kg} \mathrm{~m}^{-1}$ (V9), goat manure applied at $3 \mathrm{~kg} \mathrm{~m}^{-1}(\mathrm{GM})$ and inorganic fertilisation treatment (IF) as a control.

Compost derived from the aerobic degradation of tomato vegetal residues, vermicompost derived from the bioxidation and transformation of tomato vegetal residues of the previous crop, through the combined action of worms (Eisenia fetida), and microorganisms under aerobic and mesophilic conditions were produced by TECOMSA S.L. The manure used was obtained from the aerobic fermentation of goat excrement. The green manure was made of vegetal residues of the previous tomato crop, chopped into pieces of $2 \mathrm{~cm}$. The organic amendments were incorporated and mixed in the soil of the organic plots before 
transplanting, and no chemical fertilisers were added. The amendments were applied, taking as a reference the common agriculture practice in Almeria horticulture. The goat manure is commonly applied at $3 \mathrm{~kg} \mathrm{~m}^{-1}$ before transplanting. Compost and vermicompost at $3 \mathrm{~kg} \mathrm{~m}^{-1}$ were applied considering the similar total $\mathrm{N}$ concentration to goat manure. All the fresh residues generated in the previous crop cycle were incorporated into the soil, resulting in $4 \mathrm{~kg} \mathrm{~m}^{-1}$. A higher dose of vermicompost, $9 \mathrm{~kg} \mathrm{~m}^{-1}$, was tested to evaluate the possible improvement of tomato cultivation. The characteristics of organic amendments are presented in Table 2.

Table 2. Physiochemical proprieties of materials used as amendment: GM (goat manure); CR (crop residues); $\mathrm{CO}$ (compost); V (vermicompost).

\begin{tabular}{cccccccccc}
\hline & pH & E.C. & O.M & N Kjeldahl & C/N & P & K & Ca & Mg \\
\hline GM & 9.6 & 7.73 & 30.2 & 1.35 & 11 & 0.53 & 2.18 & 3.28 & 0.91 \\
CR & 6.9 & 10.79 & 75.5 & 2.50 & 15 & 0.89 & 3.39 & 4.34 & 0.72 \\
CO & 8.3 & 12.30 & 21.4 & 1.20 & 8.9 & 0.67 & 2.84 & 8.00 & 1.51 \\
V & 8.3 & 3.39 & 17.2 & 1.11 & 7.7 & 0.64 & 0.77 & 7.80 & 1.31 \\
\hline
\end{tabular}

$\mathrm{pH}$ (volume material/water 1:5); E.C. (electrical conductivity, $\mathrm{dS} \mathrm{m}^{-1}$ ); O.M. (organic matter, \% dry matter (dm)); N Kjeldahl (nitrogen Kjeldahl, \% dm); P (phosphorous; \% dm); K (potassium, \% dm); Ca (calcium, \% dm); $\mathrm{Mg}$ (magnesium, \% dm).

The control treatment did not receive any organic amendment and was fertigated with a nutrient mineral solution $\left(\mathrm{mmol} \mathrm{L}^{-1}\right)$ : $\mathrm{NO}_{3} 12.93, \mathrm{NH}_{4} 1.54, \mathrm{PO}_{4} 0.89, \mathrm{~K} 3.60$, Ca 1.80, $\mathrm{Mg}$ 1.60, $\mathrm{Na} 13.21, \mathrm{Cl} 11.55$, and the $\mathrm{pH}$ was adjusted with nitric acid.

A lysimeter $(3 \mathrm{~m} \times 0.50 \mathrm{~m})$ per treatment was placed at an angle at $0.7 \mathrm{~m}$ and $0.9 \mathrm{~m}$ depths. Each lysimeter collected the irrigation from 6 droppers with a flow rate per dropper of $3 \mathrm{~L} \mathrm{~h}^{-1}$ which was applied to three plants. The decision parameter used to determine the frequency of irrigation was the electrical conductivity (E.C.) of the drainage (Increasing the number of irrigations to keep the E.C. $\left.<6.0 \mathrm{dS} \mathrm{m}^{-1}\right)$ and the daily percentage of drainage collected in relation to the control dripper (10-15\%).

A completely randomised experimental design with six treatments and four replicates per treatment with four plants each was conducted.

\subsection{Sampling and Analyses}

\subsubsection{Yield}

To record yield, the fruits were harvested, counted and weighed with an electric balance with auto calibration. The harvest began 88 days after transplanting (DAT) and ended at 159 DAT, for a total of seven harvests.

\subsubsection{Physical Analysis of Fruits}

For each harvest, two fruits per replicate at the adequate ripening stage were randomly selected and analysed for soluble solids, moisture and colour. Then, they were homogenised for chemical analysis [23].

The total soluble solids (SS) were measured with a manual refractometer (Atago model Digital PAL-1, ATAGO CO., LTD., Tokyo, Japan), with a scale of 0 to $35^{\circ}$ Brix and 0.2 precision.

Before performing the analyses, the samples were washed, firstly with running water and then with distilled water, and residual moisture was evaporated at room temperature [19].

\subsubsection{Colour Evaluation of Fruits}

The colour measurements of tomato samples were performed as previously described [23], using a colorimeter (Spectrophotometer CM-3500D; Konika Minolta, Madrid, Spain). The colour coordinates L* (luminosity: 0, black to 100, white), $\mathrm{a}^{*}$ (variation from greenness to redness: -60 to 60 ), $b^{*}$ (variation from blueness to yellowness: -60 to 60 ) 
(CIELAB system) were determined. Each record was an average of three measurements on every tomato sample. One measure was taken in the equatorial region and the other two in the distal area of the pericarp [23].

The chromatic attributes chroma $(\mathrm{C})$, colour index $(\mathrm{CI})$, and $\mathrm{a}^{*} / \mathrm{b}^{*}$ ratio was calculated from the CIELAB coordinates, according to the following equations:

$$
\begin{gathered}
C=\left(a^{*} 2+b^{*} 2\right)^{1 / 2} \\
C I=1000 a^{*} /\left(L^{*} b^{*}\right)
\end{gathered}
$$

\subsubsection{Chemical Parameters of Fruits}

The humidity was determined by drying a representative $2 \mathrm{~g}$ sample in an oven with air circulation at $100-105{ }^{\circ} \mathrm{C}$ for $40 \mathrm{~h}$ [19].

Extraction and analysis of carotenoids ( $\beta$-carotene and lycopene) was accomplished as previously described [19]. The extraction was carried out in acetone, then the extract was saponified $[19,23]$. The carotenoid residue was dissolved in a mixture of methanol, and then the solution was filtered and analysed with HPLC-mass spectrometry, analyses were made with a Hewlett-Packard HP11100 [19]. Phenolics were extracted as previously described [24], and UHPLC-Orbitrap-MS analysis was carried out by using an UHPLCOrbitrap-MS (Thermo Fisher Scientific, San Jose, CA, USA) [23,24]. For the extraction of sterol and tocopherols, saponification was carried out as previously reported [25]. Sterols were then analysed with HPLC-mass spectrometry [25], and tocopherols were analysed according to Fabrikov et al. [25]. Ascorbic acid was determined by the 2,6-dichlorophenolindophenol titration procedure [26].

\subsubsection{Chemical Characteristics of the Soil}

To perform the chemical soil analysis, for each treatment, a soil sample was collected on 15/11/2019. Each soil sample was composed of 15 subsamples, collected randomly inside the plots, at approximately $15 \mathrm{~cm}$ depth, close to the root zone. No statistical analysis was performed, since the subsamples were mixed and collected in the same plastic bag.

The soil chemical analysis was carried out in a certified centre (Laboratorio Agroambiental FRAISORO, UNE EN ISO 17025, Gipuzkoa, Spain). The UNE 77318:2001 and ADAS (Agricultural Development and Advisory Service) methods were followed. Soil pH was determined in water suspensions at a ratio of 1:2.5 (soil/water) with a glass electrode [27]. The electrical conductivity (EC) was determined in a calcium sulphate suspension and measured with a glass electrode [28]. Organic matter (OM) was measured as equal loss on dry incineration at $450^{\circ} \mathrm{C}$ and expressed as a percentage [28]. The $\mathrm{C} / \mathrm{N}$ ratio was calculated by gas chromatography and a thermal conductivity detector (PerkinElmer®EA2400). N Kjeldahl was determined according to the Kjeldahl method [29]. Available nitrate nitrogen $\left(\mathrm{N}_{-} \mathrm{NO}_{3}{ }^{-}\right)$was extracted with calcium sulphate and determined with an electrode. Soilavailable phosphorus $\left(\mathrm{PO}_{4}{ }^{2-}\right)$ was extracted with sodium bicarbonate (Olsen Method) and determined by ionic chromatography [27]. Cations (calcium $\left(\mathrm{Ca}^{2+}\right)$, magnesium $\left(\mathrm{Mg}^{2+}\right)$, potassium $\left(\mathrm{K}^{+}\right)$, and sodium $\left(\mathrm{Na}^{+}\right)$were extracted with ammonium acetate and measured using atomic absorption spectrometry [27].

\subsection{Statistical Analysis}

For statistical analysis, Statgraphics 18 software was used. A multifactorial analysis of variance (ANOVA) at $p<0.05$ was carried out to compare the effects of different fertilisation treatments on yield and tomato quality. Principal component analysis and a simple regression were also performed to correlate the soil chemical analysis with the yield and quality of tomatoes. 


\section{Results and Discussions}

\subsection{Tomato Yield}

The treatments had statistically significant effects on tomato yield $\left(\mathrm{kg} \mathrm{m}^{-2}\right)$ (Table 3). The highest mean yield $\left(5.00 \mathrm{~kg} \mathrm{~m}^{-2}\right)$ was obtained in the treatment with inorganic fertilisation (IF), followed by vermicompost treatments (V3, V9), which did not show significant differences.

Table 3. Effect on fruit yield $\left(\mathrm{kg} \mathrm{m}^{-2}\right)$ and fruit number $\left(\mathrm{N} \mathrm{m}^{-2}\right)$ in tomato crop fertilised with inorganic fertilisers (IF), goat manure at $3 \mathrm{~kg} \mathrm{~m}^{-1}(\mathrm{GM})$, crop residue at $4 \mathrm{~kg} \mathrm{~m}^{-1}$ (CR), compost at $3 \mathrm{~kg} \mathrm{~m}^{-1}(\mathrm{CO})$, vermicompost at $3 \mathrm{~kg} \mathrm{~m}^{-1}$ (V3) and $9 \mathrm{~kg} \mathrm{~m}^{-1}$ (V9).

\begin{tabular}{|c|c|c|c|}
\hline \multirow{2}{*}{$\begin{array}{l}\text { Treatments } \\
\text { IF (Control) }\end{array}$} & \multicolumn{2}{|c|}{ Fruit Yield (kg m$\left.{ }^{-2}\right)$} & \multirow{2}{*}{$\frac{\mathbf{N}^{\circ} \text { Fruits }\left(\mathbf{N ~ m}^{\mathbf{2}}\right)}{72.88}$} \\
\hline & 5.00 & a & \\
\hline GM & 4.10 & $\mathrm{~b}$ & 66.22 \\
\hline CR & 4.14 & $\mathrm{~b}$ & 65.12 \\
\hline $\mathrm{CO}$ & 4.32 & $\mathrm{~b}$ & 66.80 \\
\hline V3 & 4.50 & $\mathrm{ab}$ & 66.50 \\
\hline \multirow[t]{2}{*}{ V9 } & 4.43 & $a b$ & 68.97 \\
\hline & * & & ns \\
\hline
\end{tabular}

* Different letters in the same column indicate significant differences between treatments according to the LSD test $(p \leq 0.05)$; ns: not significant.

The organic treatments with fresh crop residue (CR), composted goat manure (GM) and composted vegetable waste $(\mathrm{CO})$ showed significant lower yields $\left(\mathrm{kg} \mathrm{m}^{-2}\right)$ compared with the inorganic fertiliser (IF).

These results are in line with previous studies, which reported higher tomato yields with the application of chemical fertilisers compared with organic management $[21,30]$. The main issue in organically managed soil is the slow release of nutrients, especially $N$, from the organic matter, which limits the conditions for plant growth [4]. However, plots where vermicompost (V3, V9) was applied did not show significant differences in yields compared to inorganic fertilized plots. In line with our study's results, Murmu et al. [31] reported a similar tomato yield when a full dose of inorganic fertiliser and a full dose of vermicompost were applied. The results obtained can be ascribed to the high fraction of degraded organic matter in vermicompost, which results in higher nutrient availability compared to the other organic amendments. Vermicompost also contains humic acid, which can enhance the release of cations and promote plant growth [31]. Moreover, vermicompost can improve the N-fixing microorganism concentration in the soil, which leads to a high availability of $\mathrm{N}$ [22]. No significant differences were found in the number of tomatoes (Table 3).

\subsection{Tomato Quality}

\subsubsection{Tomato Physical Proprieties}

The soluble solids content (SS) in tomatoes ranges between 5 and 7 [32]. In this experiment, no significant differences were found between treatments (Table 4). The results are in accordance with previous studies which obtained no differences in soluble solids content between different fertilisation treatments [33]. Ferreira et al. [32] stated that cultural conditions do not affect the content of soluble solids in tomato.

Fruit colour is one of the most important tomato quality parameters, and it is due to the content of carotenoids [34]. $\mathrm{L}^{*}$ represents the lightness of the tomato colour, and greater values were observed in tomatoes treated with vermicompost applied at $9 \mathrm{~kg} \mathrm{~m}^{-1}$ (V9), compost (CO) and crop residue (CR). Bilalis et al. [21] reported higher $\mathrm{L}^{*}$ values in tomato fruits fertilised with compost compared to the tomato fruits treated with inorganic fertilisers. 
Table 4. Effect on soluble solids (SS) content $\left({ }^{\circ}\right.$ Brix), and fruit colours $\left(\mathrm{L}^{*}, \mathrm{a}^{*}, \mathrm{~b}^{*}, \mathrm{CI}, \mathrm{C}, \mathrm{a}^{*} / \mathrm{b}^{*}\right)$ in tomato crop fertilised with inorganic fertilisers (IF), goat manure at $3 \mathrm{~kg} \mathrm{~m}-1$ (GM), crop residue at $4 \mathrm{~kg} \mathrm{~m}^{-1}(\mathrm{CR})$, compost at $3 \mathrm{~kg} \mathrm{~m}^{-1}(\mathrm{CO})$, and vermicompost at 3 (V3) and $9 \mathrm{~kg} \mathrm{~m}^{-1}$ (V9).

\begin{tabular}{|c|c|c|c|c|c|c|c|c|c|c|c|c|c|}
\hline \multirow[b]{2}{*}{ IF } & \multirow{2}{*}{$\begin{array}{c}\begin{array}{c}\text { SS } \\
\left({ }^{\circ} \text { Brix }\right)\end{array} \\
5.68\end{array}$} & \multicolumn{2}{|c|}{$L^{*}$} & \multicolumn{2}{|c|}{$a^{*}$} & \multicolumn{2}{|c|}{$\mathbf{b}^{*}$} & \multicolumn{2}{|c|}{ CI (Colour Index) } & \multicolumn{2}{|c|}{ C Chroma } & \multicolumn{2}{|c|}{$\begin{array}{c}\text { Brightness } \\
\left(\mathrm{a}^{*} / \mathbf{b}^{*}\right)\end{array}$} \\
\hline & & 39.50 & $\mathrm{~b}$ & 21.20 & $\mathrm{a}$ & 20.00 & $\mathrm{~d}$ & 26.93 & a & 29.15 & bc & 1.06 & $\mathrm{a}$ \\
\hline GM & 5.69 & 40.40 & $\mathrm{~b}$ & 18.20 & c & 23.80 & $\mathrm{~b}$ & 18.91 & $\mathrm{~b}$ & 29.96 & $a b$ & 0.76 & c \\
\hline CR & 5.49 & 42.80 & $\mathrm{a}$ & 16.90 & $\mathrm{~d}$ & 21.80 & c & 18.15 & $\mathrm{~b}$ & 27.58 & $\mathrm{~d}$ & 0.78 & $\mathrm{C}$ \\
\hline $\mathrm{C} 0$ & 5.88 & 43.30 & $\mathrm{a}$ & 16.50 & $\mathrm{~d}$ & 25.80 & a & 14.75 & c & 30.63 & a & 0.64 & $\mathrm{~d}$ \\
\hline V3 & 5.64 & 40.10 & $\mathrm{~b}$ & 19.90 & $\mathrm{~b}$ & 20.60 & d & 24.27 & a & 28.65 & $\mathrm{~cd}$ & 0.97 & $\mathrm{~b}$ \\
\hline V9 & 5.91 & 43.90 & $\mathrm{a}$ & 15.50 & $\mathrm{e}$ & 20.50 & d & 17.26 & bc & 25.70 & $\mathrm{e}$ & 0.76 & c \\
\hline
\end{tabular}

${ }^{*}$ Different letters in the same column indicate significant differences between treatments according to the LSD test $(p \leq 0.05)$; ns: not significant.

The $\mathrm{a}^{*}$ value indicates the intensity of red colour, and it is related to the lycopene content [35], with higher $\mathrm{a}^{*}$ values more desirable in red tomatoes [36]. The $\mathrm{a}^{*}$ value was significantly different among the treatments. Contrary to the results of Bilalis et al. [21] and Viskelis et al. [37], in this study, the highest a* value was obtained with conventional fertilisation management, which was also the treatment with the highest lycopene concentration (Table 5).

Table 5. Effect on fruit chemicals composition in tomato crop fertilised with inorganic fertilisers (IF), goat manure (GM), crop residue (CR), compost (CO), and vermicompost at 3 (V3) and $9 \mathrm{~kg} \mathrm{~m}^{-1}$ (V9).

\begin{tabular}{|c|c|c|c|c|c|c|c|}
\hline & $\begin{array}{l}\text { Moisture } \\
\left(\mathrm{g} \cdot 100 \mathrm{~g}^{-1}\right)\end{array}$ & $\begin{array}{c}\beta \text {-Carotene } \\
\left(\mathrm{mg} \cdot \mathrm{kg}^{-1}\right)\end{array}$ & $\begin{array}{c}\text { Lycopene } \\
\left(\mathrm{mg} \cdot \mathrm{kg}^{-1}\right)\end{array}$ & $\begin{array}{l}\text { Total Sterols } \\
\left(\mathrm{mg} \cdot \mathrm{kg}^{-1}\right)\end{array}$ & $\begin{array}{c}\text { Total } \\
\text { Tocopherols } \\
\left(\mathrm{mg} \cdot \mathrm{kg}^{-1}\right)\end{array}$ & $\begin{array}{c}\text { Total } \\
\text { Phenolics } \\
\left(\mathrm{mg} \cdot \mathrm{kg}^{-1}\right)\end{array}$ & $\begin{array}{c}\text { Ascorbic Acid } \\
\left(\mathrm{mg} \cdot \mathrm{kg}^{-1}\right)\end{array}$ \\
\hline IF & $94.6 \mathrm{a}$ & $2.4 \mathrm{~b}$ & $51.4 \mathrm{a}$ & $70.5 \mathrm{~d}$ & $6.3 \mathrm{e}$ & $58.5 \mathrm{bc}$ & $190.0 \mathrm{~b}$ \\
\hline GM & $94.5 \mathrm{a}$ & $6.5 \mathrm{a}$ & $36.9 \mathrm{~b}$ & $94.8 \mathrm{a}$ & $9.1 \mathrm{a}$ & $85.5 \mathrm{a}$ & $284.0 \mathrm{a}$ \\
\hline CR & $93.9 \mathrm{a}$ & $6.4 \mathrm{a}$ & $30.6 \mathrm{c}$ & $67.8 \mathrm{e}$ & $7.6 \mathrm{abc}$ & $55.1 \mathrm{c}$ & $107.0 \mathrm{c}$ \\
\hline $\mathrm{CO}$ & $94.3 \mathrm{a}$ & $7.2 \mathrm{a}$ & $35.6 \mathrm{~b}$ & $73.0 \mathrm{c}$ & $7.1 \mathrm{~cd}$ & $50.8 \mathrm{c}$ & $124.0 \mathrm{c}$ \\
\hline V3 & $94.8 \mathrm{a}$ & $5.7 \mathrm{ab}$ & $49.7 \mathrm{a}$ & $51.0 \mathrm{f}$ & $6.8 \mathrm{de}$ & $66.3 \mathrm{~b}$ & $113.0 \mathrm{c}$ \\
\hline \multirow[t]{2}{*}{ V9 } & $93.9 \mathrm{a}$ & $8.0 \mathrm{a}$ & $35.5 \mathrm{~b}$ & $86.4 \mathrm{~b}$ & $8.0 \mathrm{~b}$ & $79.2 \mathrm{a}$ & $267.0 \mathrm{a}$ \\
\hline & $*$ & $*$ & * & $*$ & $*$ & $*$ & $*$ \\
\hline
\end{tabular}

* Different letters in the same column indicate significant differences between treatments according to the LSD test $(p \leq 0.05)$.

The $b^{*}$ value indicates the yellow colour of fruits [38], and it was higher in the compost treatment $(\mathrm{CO})$ followed by manure $(\mathrm{GM})$ and crop residue $(\mathrm{CR})$ treatments.

Concerning the colour index CI, which reflects the visual appearance of the fruit [39], C, which represents colour saturation and increases during the ripening of fruits [35], and brightness $\left(\mathrm{a}^{*} / \mathrm{b}^{*}\right)$, the highest values were obtained in inorganic treatments and vermicompost at the lowest doses, except for $\mathrm{C}$, which presented the best result in the compost treatment (CO). Similarly, previous studies reported lower $\mathrm{a}^{*} / \mathrm{b}^{*}$ values in the organic fertilisation regime $[30,40]$.

\subsubsection{Tomato Chemicals Proprieties}

The chemical analysis results are shown in Table 5.

Several studies reported that fruit quality is related to genetics, agronomic and environmental factors $[13,41]$.

It has been reported that organic tomatoes contain higher amounts of phytochemicals compared with conventional ones [42-44], although Ulrichs et al. [45], analysing nutritional parameters, found no differences between tomatoes grown under conventional and organic 
farming conditions, and the comparative study of Vélez-Terreros et al. [17] stated that there was no evidence that organic tomatoes had higher nutritional quality.

The water content of fruit influences the texture and taste of tomatoes [41]. In this experiment, no significant differences were observed between treatments (Table 5). In contrast, different studies reported different moisture levels in tomato fruits depending on fertilisation treatment $[39,46]$.

Regarding $\beta$-carotene, the lowest level was found in the IF treatment, with no significant differences with the V3 treatment. The organic treatments GM, CR, CO and V9 showed significantly higher $\beta$-carotene content (Table 5 ). This finding is in line with the results of Pertopoulous et al. [39], who reported a beneficial effect in terms of carotenes content in tomato fruits under organic fertilisation. Caris-Veyrat et al. [47] also found a higher amount of $\beta$-carotene in organic tomatoes compared to tomatoes cultivated conventionally.

Lycopene constitutes about $80 \%$ of total carotenoids in red tomato fruit [45]. The lycopene level was higher in the control (IF) and in the vermicompost treatment at lower doses (V3). Tomatoes collected from the CR treatment had the lowest level of lycopene (Table 5). The results are in agreement with the study of Abu-Zahra et al. [15], which obtained bell peppers with higher lycopene when mineral fertilisers were applied, compared to different animal manure amendments treatments. Murmu et al. [31] found the highest lycopene content in tomato when an optimal dose of fertiliser was applied, either from a mineral or organic source. Otherwise, the results are controversial. Bilalis et al. [21] obtained tomatoes with a higher lycopene content when seaweed compost was applied compared with tomatoes fertilised with chemicals. Vinha et al. [43], comparing tomatoes managed with organic fertilisation and biological pest control with tomatoes grown conventionally, reported that organic tomatoes accumulated higher concentrations of lycopene, while Borguini et al. [42] found no significant differences between organic and conventional tomatoes in terms of lycopene content.

Total sterols and total tocopherols constitute a large fraction of the unsaponifiable materials of vegetable oils [48], having important antioxidant activity in tomato. The GM treatment, followed by the V9 treatment, exhibited the best results (Table 5). Similarly, Petropoulous et al. [39] found the highest tocopherol content in tomatoes fertilised with composted sheep manure.

Phenolics are important nutritional compounds in tomatoes [17]. The content of total phenolics was higher in GM and V9, with the lowest values in CR and CO. The amount of phenolics found in IF showed no significant difference from CR and CO. The restricted use of chemicals is reported to accelerate the synthesis of phenolic compounds [49]. Different studies found a higher level of phenolics in organic tomatoes than in those fertilised with chemicals $[42-44,50]$. In accordance with the previous results, in this study, the phenolic content depends on the nutritional source.

Ascorbic acid is a powerful antioxidant, and its concentration in fruit is mainly influenced by genetics and environmental conditions [39]. Several authors have found higher ascorbic acid content in organic tomatoes [44,47], although Vélez-Terrero [17], comparing results from different studies, found that the concentration of ascorbic acid in tomatoes is similar between organic and conventional crop management. The results presented show differences in the ascorbic acid content depending on the fertilisation regime. The highest and significant results were obtained in organic treatments with goat manure (GM) and vermicompost at the highest concentration (V9). Similarly, Wang et al. [22] obtained a higher ascorbic acid content in tomatoes fertilised with vermicompost. V3, CR and CO presented a lower content of ascorbic acid, and IF presented an intermediate result.

\subsection{Soil Chemical Properties}

Table 6 shows the chemical properties of the soil of different plots. 
Table 6. Effects on soil chemical proprieties in tomato crops fertilised with inorganic fertilisers (IF), goat manure (GM), crop residue (CR), compost (CO), vermicompost at 3 (V3) and $9 \mathrm{~kg} \mathrm{~m}^{-1}$ (V9), during the tomato crop cycle $(15 / 11 / 2019)$.

\begin{tabular}{|c|c|c|c|c|c|c|c|c|c|c|c|c|}
\hline & $\mathrm{pH}$ & E.C. & O.M. & N Kjeldahl & $\mathrm{C} / \mathrm{N}$ & $\mathrm{N}-\mathrm{NO}_{3}{ }^{-}$ & $\mathrm{PO}_{4}{ }^{2-}$ & $\mathrm{K}^{+}$ & $\mathrm{Ca}^{2+}$ & $\mathrm{Mg}^{2+}$ & $\mathrm{Na}^{+}$ & CEC \\
\hline IF & 8.6 & 2330 & 0.50 & 0.05 & 5.8 & 26.9 & 170 & 1260 & 5320 & 1030 & 771 & 41.6 \\
\hline GM & 8.7 & 2630 & 0.42 & 0.05 & 4.9 & 12.9 & 113 & 1390 & 5360 & 820 & 965 & 41.3 \\
\hline CR & 8.6 & 1960 & 0.58 & 0.05 & 6.7 & 8.8 & 190 & 697 & 5230 & 1030 & 506 & 38.6 \\
\hline $\mathrm{CO}$ & 8.8 & 2240 & 1.04 & 0.08 & 7.6 & 9.9 & 311 & 998 & 5140 & 1050 & 735 & 40.1 \\
\hline V3 & 8.7 & 2330 & 0.63 & 0.06 & 6.1 & 11.0 & 198 & 889 & 5230 & 972 & 780 & 39.8 \\
\hline V9 & 8.9 & 2110 & 0.45 & $<0.05$ & 6.5 & 9.8 & 123 & 1000 & 5400 & 1010 & 626 & 40.6 \\
\hline
\end{tabular}

$\mathrm{pH}$ (volume soil-water 1:2.5); E.C. (electrical conductivity, $\mu \mathrm{S} \mathrm{cm}^{-1}$ ); O.M. (organic matter, \% dry matter (dm)); $\mathrm{N}$ Kjedlahl (nitrogen Kjedlahl, \% dm); N-NO ${ }^{-}$(nitrate nitrogen, $\mathrm{mg} \mathrm{L}^{-1}$ ); $\mathrm{PO}^{2-}$ (phosphate, $\mathrm{mg} \mathrm{L}^{-1}$ ); $\mathrm{K}^{+}\left(\mathrm{potas}^{-}\right.$ sium, $\mathrm{mg} \mathrm{L}^{-1}$ ); $\mathrm{Ca}^{2+}$ (calcium, $\mathrm{mg} \mathrm{L}^{-1}$ ); $\mathrm{Mg}^{2+}$ (magnesium, $\mathrm{mg} \mathrm{L}^{-1}$ ); $\mathrm{Na}^{+}$(sodium, $\mathrm{mg} \mathrm{L}^{-1}$ ); CEC (cations exchange capacity, meq $100 \mathrm{~mL}^{-1}$ ). Each soil sample was composed of 15 subsamples, collected randomly inside the plots. No statistically analysis was performed since the subsamples were mixed and collected in the same plastic bag.

Soil $\mathrm{pH}$ and electrical conductivity (E.C.) were not affected by fertilisation treatments, as reported in another paper by Hernández et al. [11].

The results underline that nitrate nitrogen $\left({\mathrm{N}-\mathrm{NO}_{3}}^{-}\right)$was the highest in soil where inorganic fertiliser was applied. This is due to the continuous $\mathrm{N}^{-\mathrm{NO}_{3}}{ }^{-}$supplied by fertigation. The results are in line with previous studies, which reported a higher total $\mathrm{N}$ content with inorganic fertilisation management compared to soil managed with organic amendments [4].

It is also clear that the application of compost (CO) allowed us to increase soil phosphorus $\left(\mathrm{PO}^{2-}\right.$ ) availability, which was $45 \%$ higher than the soil fertilised with minerals (IF). This may be ascribed to the high phosphatase activity conferred with compost application [28]. Organic matter from compost or vermicompost increases the microbial population that improves the solubility and mineralization of phosphorus [28].

Regarding cation concentrations in the suspension solution, potassium $(\mathrm{K}+)$ showed differences between treatments, with the highest absolute value in IF and GM plots, while the lowest concentration was observed in CR treatment plot. Although the amendment derived from crop fresh residues $(\mathrm{CR})$ has the highest $\mathrm{K}(\% \mathrm{dm})$ concentration (Table 2), plots treated with this amendment resulted in the lowest soil $\mathrm{K}+$ concentration, probably due to the high retention of $\mathrm{K}$ in the vegetal tissue, not available for plants.

No statistical analysis was performed with soil chemical proprieties. These results were used to understand the correlation between tomato yield and quality and soil chemical proprieties affected by fertilisation management.

\subsection{Influence of Soil Proprieties on Tomato Yield and Quality}

In order to establish relationships between tomato yield and quality, and chemical proprieties of the soil, a principal component analysis (PCA) was performed. PCA is a useful method which reduces the number of variables to a limited number of principal components, allowing to understand relations between factors in complex biological systems [51].

PCA (Figure 3) was carried out including all the variables presented previously: yield $\left(\mathrm{kg} \mathrm{m}^{-2}\right)$ (Table 3), quality parameters (Tables 4 and 5) and soil chemical analysis (Table 6). The variables that did not show a strong influence on the model were removed from the analysis. After eliminating the non-representative variables, the two first principal components explained $32.61 \%$ and $38.33 \%$, respectively, of the total variance.

The biplot shows single variables, represented by the segment, and points stand for different treatments.

$\mathrm{N}-\mathrm{NO}_{3}{ }^{-}$is positively correlated with the yield of tomatoes $(\mathrm{r}=0.8400, p<0.05)$, as

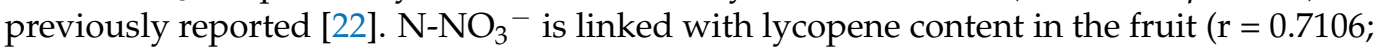
$p=0.1135)$ and colour parameter $\mathrm{a}^{*}(\mathrm{r}=0.7781, p<0.10)$. The parameter $\mathrm{a}^{*}$ is related to 
lycopene content [32]. Additionally, the colour parameters CI and brightness move in the same direction.

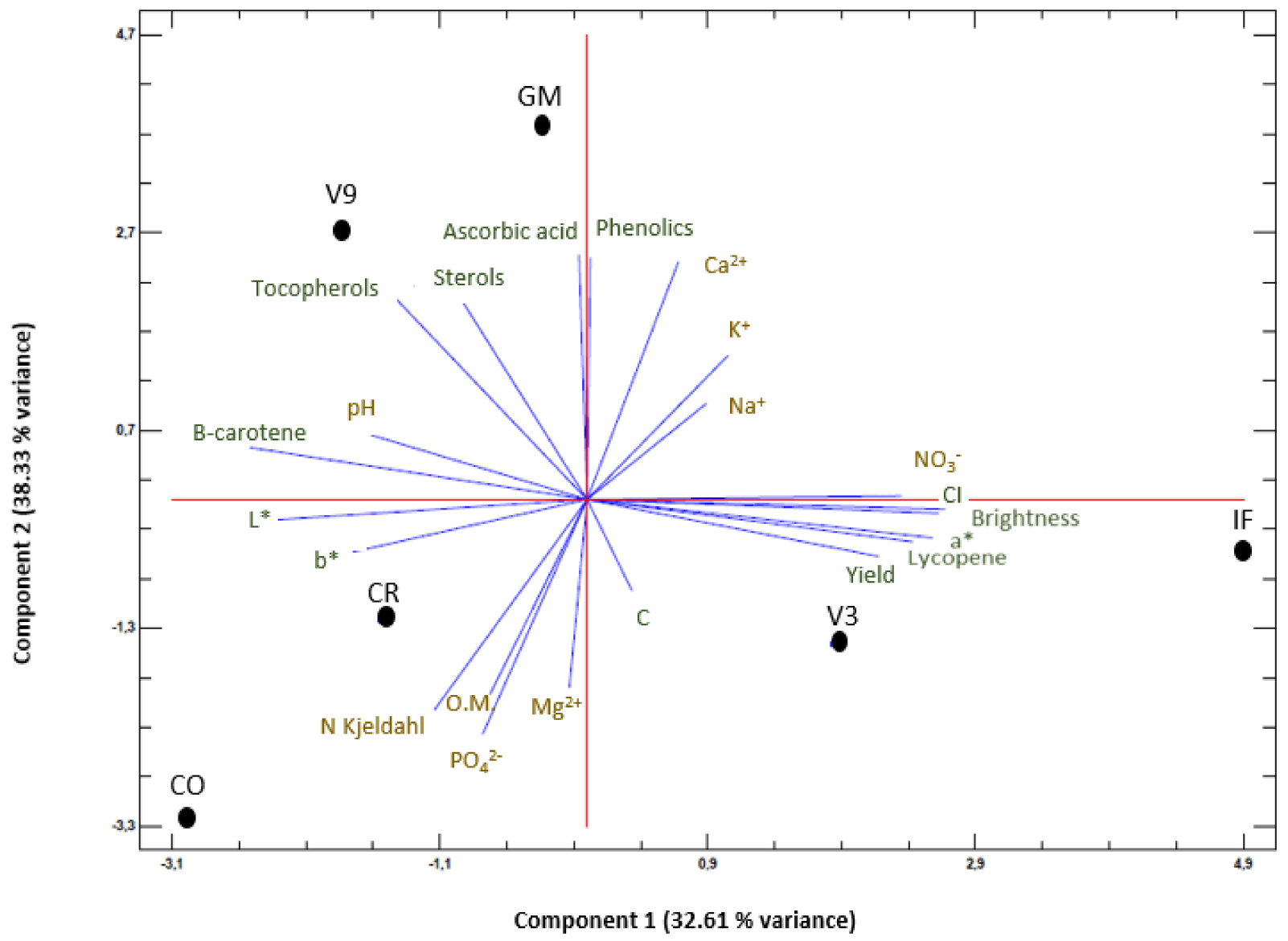

Figure 3. PCA-relationships between tomato yield, tomato quality and chemical proprieties of the soil.

It is agreed that the availability of nitrogen $(\mathrm{N})$ in the soil promotes the development of the plant and consequently the production of fruits [22]. Regarding the relation between the $\mathrm{N}$ availability and the lycopene content in fruits, the results are controversial. Zhang et al. [52] reported that $\mathrm{N}$ fertilisers mixed with manure resulted in the highest amounts of lycopene, while similarly to what was observed in this experiment, they suggested a positive correlation of $\mathrm{N}$ rates with lycopene content. In contrast, Dorais et al. [13] stated that the synthesis of secondary metabolites that are low in $\mathrm{N}$, such as lycopene, are favoured in N-limiting conditions. Other authors suggested a significant positive variation of lycopene content in processing tomato fruit, with an integrated use of compost and a half dose of recommended mineral fertiliser [53]. The IF and V3 treatments are presented in this section of the plot, indicating that results obtained with mineral and vermicompost fertilisation promotes the lycopene content and yield.

One of the main concerns in organic tomato cropping is adequate fertilisation and, especially, the availability of $\mathrm{N}-\mathrm{NO}_{3}{ }^{-}$[54], since to achieve high tomato yield, the $\mathrm{N}$ available in the soil must be equal to the plant demand [32]. In the IF treatment, nutrients are directly available for plants, while the slow rate of solarisation and mineralisation of organic matter may not meet the $\mathrm{N}$ needs of plants $[27,55]$. Furthermore, vermicompost has the largest fraction of degraded organic matter compared with the other organic amendments, resulting in higher nutrient availability. The application of vermicompost can also enhance microbial activity in the soil, thus improving the $\mathrm{N}$ availability for plants [55,56]. However, a study by Mejia et al. [28] in a soilless experiment demonstrated that higher doses of 
vermicompost lead to higher microbial activity, but the $\mathrm{N}$ concentration in the substrate does not increase. The $\mathrm{NO}_{3}{ }^{-}$is rapidly absorbed by plants and rapidly lixiviated. So, an increase in $\mathrm{N}$ concentration in the soil is not observed while increasing the vermicompost concentrations (Table 6).

Ascorbic acid, total tocopherols, total sterols and total phenolics increase jointly, opposite to the available $\mathrm{N}$ content in the soil, which implies that a low level of $\mathrm{N}$ induces higher production of these phytochemicals. A decrease in phenolics was previously observed with an increase in $\mathrm{N}$ availability [57]. Calcium (Ca) content in the soil has an influence on these variables, showing a positive and significant correlation with phenolics $(\mathrm{r}=0.8188, p<0.05)$ and ascorbic acid $(\mathrm{r}=0.8845, p<0.05)$. Ca and $\mathrm{N}$ have critical roles in cell structures and plant metabolism [58]. An improvement in fruit quality with the application of Ca was previously observed [59]. In Table 5, it is clear that the GM and V9 treatments lead to a higher concentration of ascorbic acid, tocopherols and sterols. This can be explained by the higher presence in the soil of plant growth regulators and humic acid (not analysed in this study) [60], indirectly promoting the secondary metabolic activity of tomatoes.

Except for lycopene, the higher presence of antioxidant compounds found in tomatoes treated with the highest dose of vermicompost (V9), with respect to the tomatoes treated with a $3 \mathrm{~kg} \mathrm{~m}^{-1}$ dose (V3), may be explained by the higher presence of microorganisms and an improvement in enzymatic activity when a higher dose of vermicompost is applied [56]. However, the differences in microbial activity are not completely related to the concentration of macronutrients in soil recorded in this study, and biological activity should be analysed [56] to understand the differences in results.

$\mathrm{PO}_{4}{ }^{2-}, \mathrm{N}$ Kjeldahl, $\mathrm{Mg}^{2+}$ and O.M. seem to not have affected tomato quality and yields.

$\beta$-carotene shows an opposite behaviour with respect to lycopene and is negatively correlated (statistical significance) with $\mathrm{N}_{-N_{3}}{ }^{-}(\mathrm{r}=-0.9239, p<0.05) . \mathrm{L}^{*}$ and $\mathrm{b}^{*}$ colour parameters move in the same direction.

\section{Conclusions}

In this study, the management of plant nutrition with vermicompost produced from vegetal residues of previous tomato cycles, with a standard dose of $3 \mathrm{~kg} \mathrm{~m}^{-1}$ (V3) and a higher dose of $9 \mathrm{~kg} \mathrm{~m}^{-1}$ (V9), as the sole source of nutrients, allows one to equal the yields obtained with chemical fertigation treatment (IF). Moreover, the vermicompost treatments (V3, V9) resulted in high-nutritional quality tomatoes, since vermicompost at $3 \mathrm{~kg} \mathrm{~m}^{-1}$ (V3) allows one to obtain a higher lycopene content, equal to IF treatment. Additionally, the tomatoes treated with vermicompost at $9 \mathrm{~kg} \mathrm{~m}^{-1}$ (V9) showed an improvement in the synthesis of secondary metabolites, possibly related to the higher presence in the soil of plant growth regulators and humic acid [58], indirectly promoting secondary metabolism.

It can be concluded that the use of vermicompost resulted in the best circular solution, since it allows one to reuse and recycle vegetal residues generated in an intensive crop system [3], resolving the problem of waste management and closing the nutrient cycle. The quality of this processed amendment, used as the only source of nutrients over 3 years, allowed us to obtain the same yield (no significant differences) as standard mineral fertigation management, in addition to an improvement in the concentration of antioxidants (V9) and high concentration of lycopene (V3).

A change in agricultural practices is needed to face the environmental problems caused by intensive production systems and to obtain high-quality products. The reuse of vegetal residues to produce vermicompost is a circular solution that helps to reintegrate vegetal residues into the soil.

The results encourage us to continue searching for local sources of inputs which will allow for optimizing the use of resources and reducing the generation of waste. According to the results, closing the circle in the production of intensive vegetables in regard to the source of nutrients and a reduction in the amount of organic waste is possible. 
S.; Project administration, M.d.C.S.-S.; Supervision, M.d.C.S.-S.; Writing—original draft, I.C.-M., F.B. and M.d.C.S.-S.; Writing-review and editing, I.C.-M., F.B. and M.d.C.S.-S. All authors have read and agreed to the published version of the manuscript.

Funding: This research received no external funding.

Data Availability Statement: Not applicable.

Acknowledgments: Authors would like to appreciate NATURSUR S.C.A. - Unica Group for providing the field facilities to carry out the experiments.

Conflicts of Interest: The authors declare no conflict of interest.

\section{References}

1. Aznar-Sánchez, J.A.; Velasco-Muñoz, J.F.; García-Arca, D.; López-Felices, B. Identification of Opportunities for Applying the Circular Economy to Intensive Agriculture in Almería (South-East Spain). Agronomy 2020, 10, 1499. [CrossRef]

2. Toop, T.A.; Ward, S.; Oldfield, T.; Hull, M.; Kirby, M.E.; Theodorou, M.K. AgroCycle-developing a circular economy in agriculture. Energy Procedia 2017, 123, 76-80. [CrossRef]

3. Lopez, M.J.; Masaguer, A.; Paredes, C.; Perez, L.; Muñoz, M.; Salas, M.C.; Hernandez, R. De resíduos a recursos. El camino hacia la sostenibilidad. Red Española Compost. 2015, 1, 170.

4. Sánchez-Navarro, A.; Sánchez-Romero, J.A.; Salas-Sanjuan, M.C.; Bernardeau, M.A.B.; Delgado-Iniesta, M.J. Medium-Term Influence of Organic Fertilization on the Quality and Yield of a Celery Crop. Agronomy 2020, 10, 1418. [CrossRef]

5. Walling, E.; Vaneeckhaute, C. Greenhouse gas emissions from inorganic and organic fertilizer production and use: A review of emission factors and their variability. J. Environ. Manag. 2020, 276, 111211. [CrossRef]

6. Shen, W.; Hu, M.; Quian, D.; Xue, H.; Gao, N.; Lin, X. Microbial deterioration and restoration in greenhouse-based intensive vegetable production systems. Plant Soil 2021, 463, 1-18. [CrossRef]

7. Gao, W.; Yang, H.; Kou, L.; Li, S. Effects of nitrogen deposition and fertilization on $\mathrm{N}$ transformations in forest soils: A review. J. Soils Sediments 2015, 15, 863-879. [CrossRef]

8. Mona, S.; Malyan, S.K.; Saini, N.; Deepak, B.; Pugazhendhi, A.; Kumar, S.S. Towards sustainable agriculture with carbon sequestration, and greenhouse gas mitigation using algal biochar. Chemosphere 2021, 275, 129856. [CrossRef]

9. Madrid, R.; Valverde, M.; Guillén, I.; Sanchez, A.; Lax, A. Evolution of organic matter added to soils under cultivation conditions. J. Plant Natur. Soil Sci. 2004, 167, 39-44. [CrossRef]

10. Williams, H.; Colombi, T.; Keller, T. The influence of soil management on soil health: An on-farm study in southern Sweden. Geoderma 2020, 360, 114010. [CrossRef]

11. Hernández, T.; Chocano, C.; Moreno, J.L.; García, C. Use of compost as an alternative to conventional inorganic fertilizers in intensive lettuce (Lactuca sativa L.) crops-Effects on soil and plant. Soil Tillage Res. 2016, 160, 14-22. [CrossRef]

12. Liang, B.; Zhao, W.; Yang, X.; Zhou, J. Fate of nitrogen-15 as influenced by soil and nutrient management history in a 19-year wheat-maize experiment. Field Crops Res. 2013, 144, 126-134. [CrossRef]

13. Dorais, M.; Ehret, D.L.; Papadopoulos, A.P. Tomato (Solanum lycopersicum) health components: From the seed to the consumer. Phytochem. Rev. 2008, 7, 231-250. [CrossRef]

14. Fortis-Hernández, M.; Antonio-Ordoñez, E.; Preciado-Rangel, P.; Gallegos-Robles, M.A.; Vázquez-Vázquez, C.; Reyes-Gonzales, A.; Esparza-Rivera, J.R. Effect of substrate formulated with organic material on yielding, commercial and phytochemical quality, and benefit-cost ratio of tomato (Solanum lycoperdicum L.) produced under greenhouse conditions. Not. Bot. Horti. Agrobot. Cluj Napoca 2021, 49, 11999. [CrossRef]

15. Abu-Zahra, T.R. Influence of agricultural practices on fruit quality of bell pepper. Pak. J. Biol. Sci. 2011, 14, 867-881. [CrossRef]

16. Worthington, V. Nutritional Quality of Organic Versus Conventional Fruits, Vegetables, and Grains. J. Altern. Complement. Med. 2001, 7, 161-173. [CrossRef]

17. Vélez-Terreros, P.Y.; Romero-Estévez, D.; Yánez-Jácome, G.S.; Simbaña-Farinango, K.; Navarrete, H. Comparison of major nutrients and minerals between organic and conventional tomatoes. A review. J. Food Compost Anal. 2021, 100, 103922. [CrossRef]

18. Bergougnoux, V. The history of tomato: From domestication to biopharming. Biotechnol. Adv. 2014, 32, 70-189. [CrossRef] [PubMed]

19. Guil-Guerrero, J.L.; Rebolloso-Fuentes, M.M. Nutrient composition and antioxidant activity of eight tomato (Lycopersicon esculentum) varieties. J. Food Compost. Anal. 2009, 22, 123-129. [CrossRef]

20. Perveen, R.; Suleria, H.A.; Anjum, F.M.; Butt, M.S.; Pasha, I.; Ahmad, S. Tomato (Solanum lycopersicum) carotenoids and lycopene chemistry; metabolism, absorption, nutrition, and allied health claims A comprehensive review. Crit. Rev. Food. Sci. Nutr. 2015, 55, 919-929. [CrossRef] [PubMed]

21. Bilalis, D.; Krokida, M.; Roussis, I.; Papastylianou, P.; Travlos, I.; Cheimona, N.; Dede, A. Effects of organic and inorganic fertilization on yield and quality of processing tomato (Lycopersicon esculentum Mill.). Folia Hort. 2018, 30, 321-332. [CrossRef]

22. Wang, X.X.; Zhao, F.; Zhang, G.; Zhang, Y.; Yang, L. Vermicompost Improves Tomato Yield and Quality and the Biochemical Properties of Soils with Different Tomato Planting History in a Greenhouse Study. Front. Plant Sci. 2017, 8, 1978. [CrossRef] 
23. Ramos-Bueno, R.P.; Romero-González, R.; González-Fernández, M.J.; Guil-Guerrero, J.L. Phytochemical composition and in vitro anti-tumour activities of selected tomato varieties. J. Sci. Food Agric. 2017, 97, 488-496. [CrossRef]

24. Guillén, F.; Castillo, S.; Zapata, P.J.; Martínez-Romero, D.; Valero, D.; Serrano, M. Efficacy of 1-MCP treatment in tomato fruit: 2Effect of cultivar and ripening stage at harvest. Postharvest Biol. Technol. 2006, 42, 235-242. [CrossRef]

25. Fabrikov, D.; Guil-Guerrero, J.L.; González-Fernández, M.J.; Rodríguez-García, I.; Gómez-Mercado, F.; Urrestarazu, M.; Lao, M.T.; Rincón-Cervera, M.Á.; Álvaro, J.E.; Lyashenko, S. Borage oil: Tocopherols, sterols and squalene in farmed and endemic-wild Borago species. J. Food Compost. Anal. 2019, 83, 103299. [CrossRef]

26. Suárez, M.H.; Rodrìguez, E.R.; Romero, C.D. Analysis of organic acid content in cultivars of tomato harvested in Tenerife. Eur. Food Res. Technol. 2008, 226, 423-435. [CrossRef]

27. Fu, H.; Zhang, G.; Zhang, F.; Sun, Z.; Geng, G.; Li, T. Effects of continuous tomato monoculture on soil microbial properties and enzyme activities in a solar greenhouse. Sustainability 2017, 9, 317. [CrossRef]

28. Mejia, P.A.; Salas, M.C.; López, M.J. Evaluation of physicochemical properties and enzymatic activity of organic substrates during four crop cycles in soilless containers. Food Sci. Nutr. 2018, 6, 2066-2078.

29. Bremner, J.M. Organic forms of nitrogen. Methods Soil Anal. Part 2 Chem. Microbiol. Prop. 1965, 9, 1238-1255.

30. Zuba, S.N.; Nogueira, W.C.L.; Fernandes, L.A.; Sampaio, R.A.; da Costa, D.A. Yield and nutrition of tomato using different nutrient sources. Hortic. Bras. 2011, 29, 50-56. [CrossRef]

31. Murmu, K.; Ghosh, B.C.; Swain, D.K. Yield and quality of tomato grown under organic and conventional nutrient management. Arch. Agron. Soil Sci. 2013, 59, 1311-1321. [CrossRef]

32. Ferreira, M.M.M.; Ferreira, B.F.; Fontes, P.C.R.; Dantas, J.P. Qualidade de tomate em função de doses de nitrogênio e da adubação orgânica em duas estações. Hortic. Bras. 2006, 24, 141-145. [CrossRef]

33. De Matos, R.M.; Da Silva, P.F.; Neto, J.D.; De Lima, A.S.; De Lima, V.L.A.; Saboya, L.M.F. Organic fertilization as an alternative to the chemical in cherry tomato growing under irrigation depths. Biosci. J. 2021, 37, e37006. [CrossRef]

34. López, A.F.; Gómez, P.A. Comparison of color indexes for tomato ripening. Hortic. Bras. 2004, 22, 534-537. [CrossRef]

35. Nour, V.; Ionica, M.E.; Trandafir, I. Bioactive compounds, antioxidant activity and color of hydroponic tomato fruits at different stages of ripening. Not. Bot. Horti Agrobot. Cluj Napoca 2015, 43, 404-412. [CrossRef]

36. Barrett, D.M.; Weakley, C.; Diaz, J.V.; Watnik, M. Qualitative and nutritional differences in processing tomatoes grown under commercial organic and conventional production systems. J. Food Sci. 2007, 72, 441-451. [CrossRef]

37. Viskelis, P.; Radzevicius, A.; Urbonaviciene, D.; Viskelis, J.; Karkleliene, R.; Bobinas, C. Biochemical parameters in tomato fruits from different cultivars as functional foods for agricultural, industrial, and pharmaceutical uses. Plants Future 2015, 11, 45.

38. Van Roy, J.; Keresztes, J.C.; Wouters, N.; De Ketelaere, B.; Saeys, W. Measuring colour of vine tomatoes using hyperspectral imaging. Postharvest Biol. Tech. 2017, 129, 79-89. [CrossRef]

39. Petropoulos, S.A.; Fernandes, Â.; Xyrafis, E.; Polyzos, N.; Antoniadis, V.; Barros, L.; Ferreira, I.C.F.R. The optimization of nitrogen fertilization regulates crop performance and quality of processing tomato (Solanum lycopersicum L. cv. Heinz 3402). Agronomy 2020, 10, 715. [CrossRef]

40. Chassy, A.W.; Bui, L.; Renaud, E.N.; Van Horn, M.; Mitchell, A.E. Three-year comparison of the content of antioxidant microconstituents and several quality characteristics in organic and conventionally managed tomatoes and bell peppers. J. Agric. Food Chem. 2006, 54, 8244-8252. [CrossRef]

41. Dumas, Y.; Dadomo, M.; Di Lucca, G.; Grolier, P. Effects of environmental factors and agricultural techniques on antioxidant content of tomatoes. J. Sci. Food Agric. 2003, 83, 369-382. [CrossRef]

42. Borguini, R.G.; Bastos, D.H.M.; Moita-Neto, J.M.; Capasso, F.S.; Torres, E.A.F.D.S. Antioxidant potential of tomatoes cultivated in organic and conventional systems. Braz. Arch. Biol. Technol. 2013, 56, 521-529. [CrossRef]

43. Vinha, A.F.; Barriera, S.V.P.; Costa, A.S.G.; Alves, R.C.; Oliveira, M.B.P.P. Organic versus conventional tomatoes: Influence on physicochemical parameters, bioactive compounds and sensorial attributes. Food Chem. Toxicol. 2014, 67, 139-144. [CrossRef]

44. Oliveira, A.B.; Moura, C.F.H.; Gomes-Filho, E.; Marco, C.A.; Urban, L.; Miranda, M.R.A. The Impact of Organic Farming on Quality of Tomatoes Is Associated to Increased Oxidative Stress during Fruit Development. PLoS ONE 2013, 8, e56354. [CrossRef]

45. Ulrichs, C.; Fischer, G.; Büttner, C.; Mewis, I. Comparison of lycopene, $\beta$-carotene and phenolic contents of tomato using conventional and ecological horticultural practices, and arbuscular mycorrhizal fungi (AMF). Agron. Colomb. 2008, 26, 40-46.

46. Ewulo, B.S.; Ojeniyi, S.O.; Akanni, D.A. Effect of poultry manure on selected soil physical and chemical properties, growth, yield and nutrient status of tomato. Afr. J. Agric. Res. 2008, 3, 9-14.

47. Caris-Veyrat, C.; Amiot, M.J.; Tyssandier, V.; Grasselly, D.; Buret, M.; Mikolajczak, M.; Guilland, J.C.; Bouteloup, C.; Borel, P. Influence of organic versus conventional agricultural practice on the antioxidant microconstituent content of tomatoes and derived purees; consequences on antioxidant plasma status in humans. J. Agric. Food Chem. 2004, 52, 6503-6509. [CrossRef]

48. Choo, W.S.; Birch, J.; Dufour, J.P. Physicochemical and quality characteristics of cold—Press flaxseed oils. J. Food Compos. Anal. 2007, 20, 202-211. [CrossRef]

49. Hakkinen, S.H.; Torren, A.R. Content of flavonols and selected phenolic acids in strawberries and Vaccinum species: Influence of cultivar, cultivation site and technique. Food Res. Int. 2000, 33, 517-524. [CrossRef]

50. Toor, R.K.; Savage, G.P.; Heeb, A. Influence of different types of fertilisers on the major antioxidant components of tomatoes. $J$. Food Compos. Anal. 2006, 19, 20-27. [CrossRef] 
51. Fuentes, M.M.R.; Fernández, G.G.A.; Pérez, J.A.S.; Guerrero, J.L.G. Biomass nutrient profiles of the microalga Porphyridium cruentum. Food Chem. 2000, 70, 345-353. [CrossRef]

52. Zhang, E.; Duan, Y.; Tan, F.; Zhang, S. Effects of Long-term Nitrogen and Organic Fertilization on Antioxidants Content of Tomato Fruits. J. Hortic. 2016, 3, 172. [CrossRef]

53. Verma, S.; Sharma, A.; Kumar, R.; Kaur, C.; Arora, A.; Shah, R.; Nain, L. Improvement of antioxidant and defense properties of Tomato (var. Pusa Rohini) by application of bioaugmented compost. Saudi J. Biol. Sci. 2015, 22, 256-264. [CrossRef]

54. Gravel, V.; Blok, W.; Hallmann, E.; Carmona-Torres, C.; Wang, H.; Van De Peppel, A.; Golec, A.F.C.; Dorais, M.; Van Meeteren, U.; Heuvelink, E.; et al. Differences in $\mathrm{N}$ uptake and fruit quality between organically and conventionally grown greenhouse tomatoes. Agron. Sustain. Dev. 2010, 30, 797-806. [CrossRef]

55. Kiehl, E.J.; Fertilizantes Organominerais. Piracicaba: Edição do Autor. 1993. Available online: https://repositorio.usp.br/item/ 000850337 (accessed on 18 December 2021).

56. Ruiz, J.L.; Salas, M.C. Evaluation of organic substrates and microorganisms as bio-fertilisation tool in container crop production. Agronomy 2019, 9, 705. [CrossRef]

57. Doll, H.; Holm, U.; Sogaard, B.; Bay, H. Phenolic compounds in barley varieties with different degree of partial resistance against powdery mildew. Acta Hortic. 1994, 381, 576-582. [CrossRef]

58. Mumivand, H.; Babalar, M.; Hadian, J.; Fakhr-Tabatabaei, M. Plant growth and essential oil content and composition of Saturn (Satureja hortensis L.) in response to calcium carbonate and nitrogen application rates. J. Med. Plants Res. 2011, 5, 1859-1866.

59. Kadir, S.A. Fruit quality at harvest of "Jonathan" apple treated with foliarly-applied calcium chloride. J. Plant Nutr. 2005, 27, 1991-2006. [CrossRef]

60. Arancon, N.Q.; Edwards, C.A.; Bierman, P.; Welch, C.; Metzger, J.D. Influences of vermicomposts on field strawberries: 1. Effects on growth and yields. Bioresour. Technol. 2004, 93, 145-153. [CrossRef] [PubMed] 